\title{
The terrorist threat to the UK in the post-9/11 decade
}

\section{by Sir David Omand,}

\author{
Visiting Professor, War Studies Department, King's College London
}

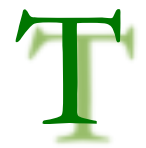

he overall task for this special issue is to assess the emergency response to terrorism, in particular the threat posed by violent jihadist terrorism. Clearly, planning for emergency responses will have value against other threats and hazards, so it will be difficult to separate out the arrangements made to deal specifically with the aftermath of terrorist attacks, and those to meet other emergencies, for example major natural disasters. A sense of proportion is also needed when examining terrorist risks: the actions of greedy market-makers and incompetent bankers in the recent past is doing much more damage to our national welfare and national security than terrorism today.

Emergency response of one kind or another has been part of this author's working life, in the Ministry of Defence, as Permanent Secretary in the Home Office and finally as Permanent Secretary in the Cabinet Office where one of the duties of the UK Security and Intelligence Coordinator was to be the UK chief crisis manager operating from the Cabinet Office Briefing Rooms, or COBR[1] -arrangements that for managing the response to terrorist incidents date back to the early 1970s when a different form of international terrorism was concerning the world after the attack by Black September on Israeli athletes at the Munich Olympic Games.

Governments tend to dislike the term 'crisis' and prefer a term like 'disruptive challenge'. Crisis implies that events are out of control and headlines about chaos are not far away. Three words 'Crisis, what crisis' in the Sun headline helped destroy the reputation of the Labour government in 1979, even though the man generally thought to have uttered them - Prime Minister Jim Callaghan on the steps of his returning aircraft from the Guadeloupe economic summit - did not in fact do so. But the words caught the popular mood that the government had lost control during the 1979 Winter of Discontent with rubbish piling up in the streets and inflation rocketing. Today, national security itself can be defined [2] as a state of confidence on the part of the public that the major risks, be they malign threats or natural hazards, are being satisfactorily managed so that people can get on with making the most of their lives, freely and with confidence. For example, for a few days in August 2011 public confidence in the ability of the authorities to provide them with security was shaken in the face of the rioting and looting in English towns and cities. Public protection thus requires that there are effective emergency responses available against the widest range of major threats and hazards. Those responses in turn depend upon prior investment in the resilience of society and its critical infrastructure and networks, human as well as electronic. All emergencies are local in impact, a fact reflected in the provisions of the UK Civil Contingencies Act 2004 with its local resilience fora.

In considering how the nation can best respond to the terrorist threat it is illuminating to start with the experience, good and bad, of the last decade, applying the benefit of some historical distance from the attacks on 9/11. That learning can provide perspective in assessing how well the UK has done in responding to the threat, especially relating to emergency response capability. 


\section{Journal of Terrorism Research}

It is a common finding of studies into crisis management that emergencies arise through two different routes: 'Sudden Impact' and 'Rising Tide'.[3] With 'Sudden Impact' events such as the bombs on the London transport system on 7/7, the Argentine invasion of the Falklands Islands or the Icelandic Ash Cloud external events burst upon us. There is no doubt in such cases that government faces an emergency and will be expected to respond promptly.

With 'Rising Tide' situations such as the UK foot and mouth disease outbreak in 2000 or the severe flooding in the West of England in 2008 the scale of emergency may not at first be apparent. Normal procedures have swung into action and only over time does it become apparent that the situation is beyond control and that emergency measures - bringing in the Armed Forces to help with the response, for example - are needed. The key, of course, to managing such situations is to have sufficiently early detection of the rising trouble so that the response can be organised before the situation worsens to crisis proportions. That is different from having early warning of the likelihood of trouble arising in the first place, allowing such advance measures as construction of flood barriers or the stockpiling of vaccines and planning mutual assistance between police forces.

That distinction between types of emergency can be applied, albeit crudely, to the UK and the US experience of terrorism over the last decade.

First of all, the threat from jihadist terrorism crept up on the public at the end of the last century as a 'rising tide' rather than a 'sudden impact'.

The first AQ car bomb attack on the World Trade Centre was in 1993. In the same year, the PIRA attacked Warrington gas works killing two children and then detonated a huge truck bomb in Bishopsgate causing around £1billion of damage. The AQ Bojinka plot in the mid-1990s was to kill 4000 people on airliners to be brought down in the Pacific. In that period PIRA set off huge bombs in South Quay in London's docklands then in the Arndale centre in Manchester. The US was becoming increasingly concerned with jihadist terrorism with the US Embassy bombings in Dar es Salaam and Nairobi in 1998, but political attention in the UK was understandably focussed on a PIRA ceasefire and the developing Northern Irish peace process.

The police and Security Service did monitor the radical preachers and known jihadist extremists, who were often motivated by anger over Kashmir - or, for some, the earlier plight of the Bosnian Muslims, or repression in Algeria and Chechnya. Bin Laden did have what was described as 'the media wing of Al Qaida' [4] in the UK and he gave interviews to the Al Quds al-Arabia newspaper based in London in 1996 and 1998 announcing his so-called fatwas declaring war on the Zionists and Western crusaders. The activities of Bin Laden were thus certainly a target for the specialists in the intelligence services, but AQ was not in the late 1990s a household term as the Provisional IRA was. It can be too readily forgotten that the first UK jihadist plot was disrupted in November 2000 when a Birmingham house and nearby lock-up were found to contain bomb-making instructions, equipment, and $100 \mathrm{~kg}$ of the chemical components of the explosive HTMD. But the major dangers from the 'rising tide' of jihadism were seen to be overseas.

So before $9 / 11$, the jihadist terrorist threat to the UK itself was thought to be manageable by the level of response then available. In a similar way, despite the evidence of the earlier AQ attack on the World Trade Centre, the US assessed the the rising tide of threat to be to primarily to US interests overseas, which is where the centre of gravity of US intelligence effort was focussed.

9/11 changed all that. It was the 'sudden impact' emergency writ large. The politics of terrorism changed overnight with the unfolding into political and public consciousness of what Fawaz Gerges later called [5] the AQ strategy to attack the 'Far Enemy' in our own homelands. The impact on the 


\section{Journal of Terrorism Research}

US - 'the Pearl Harbor effect' - was especially traumatic. The British public - in spite of the PIRA experience - shared then the fear of the enemy in hiding waiting to strike.

Public apprehension was heightened by the recognition that such suicidal jihadists would not have hesitated to use a dirty bomb or bio-terror weapon if they had them, or even a nuclear weapon if passed on by a rogue state. Western advanced societies appeared fragile and vulnerable, so improving resilience and emergency planning suddenly became a priority for government. The psychological ripples from the 9/11 impact spread of course much wider. For Tony Blair, as he explained to the Chilcot inquiry [6], it was no longer prudent to wait for the proliferator to develop his weapons and for the enemy to strike the first blow.

The attacks on $9 / 11$ provided the most dramatic call to arms possible to young radicals in Muslim communities around the world, stimulating them to action, some in conjunction with AQ planners, others largely independently. The prompt allied intervention in Afghanistan after 9/11 destroyed the AQ training camps and infrastructure that were turning out a steady output of a small number of determined professional terrorists, as well as larger numbers of foot-soldiers. That was very necessary for Western security. But one of the unwelcome consequences was the flight of AQ leaders to the FATA in Pakistan, making contacts easier between British based extremists of Pakistani descent, who could easily travel legitimately to Pakistan, and terrorist facilitators and trainers in Pakistan such as Rashid Rauf. The UK security authorities began to see more and more domestic networks of jihadist activists, with increasing talk of action against the UK itself.

That rise in domestic activism unfortunately coincided with the highly controversial $2003 \mathrm{US} / \mathrm{UK}$ invasion of Iraq that acted as an accelerant on young hot heads, as the JIC had warned it would if the UK joined the invasion. The effect was intensified by the imagery of the bloody aftermath of occupation, which the rapidly expanding internet carried globally.

UK extremists actively sought ways of getting involved in violent jihad and travelled to Pakistan to seek contacts and support. This bottom-up pressure to join the movement was of course eagerly exploited by AQ facilitators and planners. This was the period of a number of serious AQ-facilitated terrorist plots against the UK such as the terrorist plan to down half a dozen aircraft in the Atlantic using liquid explosives smuggled onboard in soft drinks bottles that would have killed more US citizens than on 9/11.[7]

The overall effect of these developments was to create a "severe" domestic threat of jihadist violence, meaning that a terrorist attack at any time was judged by the authorities (in JTAC) as highly likely. It would of course have been unrealistic to expect the security authorities to be able to frustrate every plot in advance. Met Commissioner John Stevens notoriously said to the media it was a question of when, not if. The London attacks when they came on 7/7 did not therefore arrive as a strategic surprise. Emergency responses had been prepared for just such an eventuality, including a live exercise at Bank Underground station. As Lady Justice Hallett's 7/7 inquest concluded, however, despite their best efforts the security authorities were still caught by tactical surprise.

Commentators sometimes write about the attacks on London transport on 7/7 as the UK's "wakeup" call over jihadist terrorism. That would not be true of the government and the security and intelligence community - and the media correspondents. They knew how close the nation had come in previous years to terrorist mass murder by the Crevice gang or by Richard Reid, the shoe bomber. The decision to increase greatly spending and effort on counter-terrorism had been taken two years before, including doubling the size of the Security Service, building new joint arrangements with the police outside London and investing heavily in the emergency services. It was, however, only in 2006 well after 7/7 that the UK government first published [8] a comprehensive account in a White 


\section{Journal of Terrorism Research}

Paper of the counter-terrorist strategy CONTEST it had been following since 2003. So perhaps more might have been done to educate the public before $7 / 7$ as to what the government was actually doing to keep them safe.

Continuing the narrative, the occupation of Iraq eventually ended. AQ in Iraq did not succeed in gaining power and were denounced by the Sunni community. A series of plots in the UK were uncovered and pre-empted or were launched but failed in their intent-perhaps as many as a dozen after 7/7 - and notable arrests and convictions followed. That pace of work by the security authorities has not faltered, and significant arrests continue to be made and suspects charged with terrorist offences.

In recent years, under President Obama, the intensified US intelligence-led drone and covert CT campaign has removed most of the top leadership of AQ in the FATA and elsewhere (and of course most recently killed Bin Laden himself in Pakistan). AQ's senior leadership has lost most of its major figures. The movement is more dispersed. It has also, in the eyes of the Arab street, been shown to be largely irrelevant to the Arab Spring in North Africa and Egypt, reducing its ideological appeal worldwide including the UK. The jihadist terrorist threat has shifted, with attention now focussed on Al Shabaab in Somalia and most recently on the Boko Haram group in Northern Nigeria. AQ supporters are engaged in active insurgency in Yemen, and some of them also have had contacts with would-be terrorists in the UK. In the UK there should be a sense of relief (whatever views may be held about the manner in which it happened) that their leader, Anwar al-Awlaki is dead, killed by a drone strike. He was the man behind the 2010 printer cartridge bombs one of which was recovered at East Midlands airport before it was able to explode. He was also editor of Inspire magazine, a glossy webzine that radicalised the 'lone wolf', Roshonara Chowhary, in her attempt to murder Stephen Timms MP as well as other would-be terrorists as evidence to recent court cases has shown.

The official UK jihadist threat level was reduced last year from severe to substantial - although this still means that a terrorist attack is a strong possibility (Olympic planning for 2012 is prudently based on the assumption that it could rise again to severe). It is also prudent to recall that the dissident Irish republicans have ambitions to cause trouble here. It would nevertheless be reasonable to look back over the last decade and reach the conclusion that, overall, the UK and the US are safer today than on the eve of 9/11, when it must be remembered AQ had its bases and training camps in Afghanistan, and had a cadre of dedicated and experienced terrorist operational planners to call on.

A more penetrating question would be to ask whether the UK government over-reacted over the last decade due to exaggerated perceptions of the AQ threat? Overall, my response would be in the negative. If anything, the authorities can be criticized for not pressing for a major increase in the security and resilience effort a little earlier. Although the number of deaths of British citizens caused by jihadist terrorism over the decade is, thankfully, small in relation to other everyday risk such as traffic accidents things would look very different if even a few of the major plots had succeeded.

The hard, counter-factual, question is, of course, whether the UK could have been even safer after 9/11 if different counter-terrorism and foreign policies had been adopted. There can be more than one point of view on the matter. Iraq did worsen the radicalization process, although it did not create it. Bush-era rendition and interrogation policies helped create a sense of double standards over key Western values of freedom, democracy and human rights. The very term 'war on terror' may have helped create a sense of an inevitable conflict between the West and the world of Islam. Some measures in UK counter-terrorism legislation may have been counter-productive in 


\section{Journal of Terrorism Research}

discouraging active intelligence cooperation from Muslim communities. There may therefore have been a higher price paid than need have been, but that is with the benefit of hindsight. Events never appear so clear at the time and - for example - had the US not acted against the AQ leadership and the US not been prepared to share its intelligence with the British authorities, and vice-versa, who can tell what attacks might have taken place?

The prevailing approach to domestic security planning in the UK after 9/11 was heavily influenced by the growing application of risk management as a planning tool in government generally. Risk management was built in to the British counter-terrorism strategy, CONTEST, that the author launched in November 2002. That driving logic may well be the main reason why CONTEST is still in force today under its third prime minister.

The CONTEST strategy used the risk equation to identify the different ways in which the risk to the public from terrorism can be reduced. The index of risk can be taken to be the product of different factors: likelihood of attack $\mathrm{x}$ vulnerability to attack $\mathrm{x}$ initial impact of an attack $\mathrm{x}$ duration of disruption that would result from an attack. Likelihood is reduced through strategic campaigns to improve intelligence and law enforcement to uncover terrorist networks and bring them to justice (Pursue) and by tackling the process of radicalization into violent extremism (Prevent).

Vulnerability of critical infrastructure, transport etc is reduced by investing in protective security (Protect) and the impact and duration of disruption is minimized by improving the emergency response (Prepare). The CONTEST strategic aim reflects the risk management approach by having the objective being 'to reduce the risk' from terrorism so that people could go about their normal business, freely (that is, without having to interfere with individual freedoms and liberties) and with confidence (that is, with people still travelling by air and on the underground, visitors coming to the UK, confidence in the markets and so on). A very different approach from the US "war on terror" strategy, that sought risk elimination in relation to AQ.

As a result of all these measures, in addition to reducing the likelihood of a successful attack, the UK's vulnerability as a society to terrorism has been significantly reduced. Aviation security measures, improved building standards, new surveillance technology, protection for the finance sector and other critical national infrastructure, all the measures being put in place for the Olympics in 2012 help reduce the vulnerability to attack - and much of this investment also helps reduce vulnerability to other forms of non-terrorist disruption.

And the potential impact of an attack, both in terms of initial damage and the duration of disruption, has been much reduced by the careful preparation of emergency response: command and control, communications, emergency services training, medical services, consular services overseas and local resilience networks at home and so on. The coroners report on 7/7 went over the ground in great detail, and those lessons have been absorbed by the authorities. Most commentators would accept that the UK is prepared for managing the aftermath of a range of calamities in a way that was certainly not the case at the time of $9 / 11$.

In applying the counter-terrorism strategy, it has been essential to have sound intelligence on the threat and how it has developed. The creation of the Joint Terrorism Analysis Centre, JTAC, has at the operational level improved the ability to learn how terrorists think, how they operate and about fashions in attack methodologies. That is operational information that is essential in emergency planning including for the protection of first responders.

A fundamental principle in thinking about crisis management is that all emergencies are local in their impact. Most emergencies in the United Kingdom can be perfectly well handled at a local level by the appropriate emergency services, local authorities and agencies, often involving local volunteers from St Johns Ambulance or the Red Cross, with no direct involvement from Central 


\section{Journal of Terrorism Research}

Government. The command buck stops with the local Gold Command when it comes to decisions regarding the safety of the public. But in complex emergencies there will be decisions that even a Chief Constable does not have the authority to take. Examples might be taking powers under the Civil Contingencies Act 2004, making emergency grants from the Treasury's contingency fund, authorizing the deployment of the Armed Forces, negotiating with foreign governments and placing requirements upon the intelligence services. And more fundamentally, in major emergencies there is the important matter of selecting the national strategic aim for the management of the consequences and the subsequent recovery. The experience of the last decade is that the degree of media interest increasingly influences that level of central involvement.

The British authorities have learned lessons, some the hard way, about what could be described as the 'thermodynamics' of counter-terrorism: how the government can best exercise its primary duty to protect the public in the face of a severe terrorist threat and yet maintain civic harmony and uphold democratic values and the rule of law at home and internationally. There is a relationship between the vigour of emergency measures, taken to protect the public and to obtain intelligence to prevent attacks, and the level of confidence among all sections of the community in the government's commitment to protect the liberties and rights of the citizen.

As with the thermodynamic relationship between the volume, pressure and temperature of a gas, too sudden an application of force to compress it and the temperature may rise dangerously to explosive levels; too little pressure applied and the gas is uncontained and will expand out of control. The best approach may well be to cool things down as you gradually build up the pressure, and certainly not to do things unnecessarily that heat it up - the influence of the invasion of Iraq has already been mentioned. There is after all no such thing as a risk free world and attempting ever higher levels of security will become oppressive and counter-productive.

Without pushing such an inexact analogy further, the point to be registered is that there is an interrelationship between a nation's counter-terrorism efforts, their effect on the spread of the violent jihadist ideology and on civic harmony, civil liberties, and human rights. The strategic narrative governments choose to tell about what is going on based on their assessment of the threat and of the effects of the response, direct and indirect, is crucial to getting the thermodynamic judgment right.

Terrorists are mostly creatures of habit, for which the public should be grateful. The manifestations of terrorism may well follow well understood past tactics: aircraft hijackings, car and parcel bombing campaigns, kidnappings and assassinations. There are very serious crimes and the public will rightly expect the perpetrators to be pursued with vigour. The first and main lesson from the last decade is, however, the importance of affording the time and effort at the outset to be best able to judge the underlying nature and potential gravity of a terrorist threat. Only then can leaders be in a position to be able to calibrate the response appropriately and proportionately across all the levers open to government at home and abroad. This will never be an easy undertaking and there cannot be a ready-made heuristic to apply.

Parliament, public and the media, will have (vivid) ways of expressing their own implicit risk appetites and in the aftermath of some atrocity these are unlikely to be the same as those of the security authorities. Only with a well-grounded and explicable view of the nature of the threat and the consequences of possible responses can the different considerations be brought into an acceptable equilibrium that the public will accept as the best possible in the circumstances.

The public should look to government to decide in good time whether to act to try to reduce the risk further, or to act to reduce society's vulnerability to it, or in some cases sensibly to decide to leave well alone. Anticipation places a great responsibility on the intelligence of those who are to provide strategic notice of emerging risks. That is certainly the case with terrorism, the threat that is the 


\section{Journal of Terrorism Research}

subject of this conference. It places of course even more weight on the wisdom of those who have to decide whether and how to act upon such warning. As Machiavelli advised, 'a Prince who is himself not wise cannot be well advised'.

Looking back, I would argue that the relevant UK risk judgments in the period after 9/11 have been shown to be broadly correct in the light of hindsight, although with some bumps and hard lessons learnt on the way.

About the author: Sir David Omand GCB is a visiting professor in the War Studies Department at King's College London. He was appointed in 2002 the first UK Security and Intelligence Coordinator, responsible to the Prime Minister for the professional health of the intelligence community, national counter-terrorism strategy and "homeland security". He served for seven years on the Joint Intelligence Committee. He was Permanent Secretary of the Home Office from 1997 to 2000, and before that Director of GCHQ. Previously, in the Ministry of Defence he served as Deputy Under Secretary of State for Policy, Principal Private Secretary to the Defence Secretary, and served for three years in NATO Brussels as the UK Defence Counsellor. He was educated at the Glasgow Academy and Corpus Christi College, Cambridge where he is an honorary fellow. His book, Securing the State, was published by C. Hurst (Publishers) Ltd on 1 July 2010.

\section{Notes:}

[1] UK Government, Central Government Arrangements for Responding to an Emergency, London: Cabinet Office, March 2005, http://webarchive.nationalarchives.gov.uk +http://www.cabinetoffice.gov.uk/media/132685/conops.pdf

[2] David Omand, Securing the State, London: Hurst and New York: Columbia University Press, 2010

[3] Guidance on Emergency Procedures, Association of Chief Police Officers, 2009

[4] http://www.terrorismanalysts.com/pt/index.php/pot/article/view/14/html

[5] Fawaz Gerges, The Far Enemy, Cambridge: Cambridge University Press, 2005.

[6] http://www.iraqinquiry.org.uk/transcripts/oralevidence-bydate/110121.aspx, accessed 2 March 2012.

[7] A summary of terrorist plots in the UK can be found on the MI5 web-site, https://www.mi5.gov.uk/output/terrorist-plots-in-theuk.html, accessed 1 March 2012

[8] Cm. 8123, CONTEST: The UK's Strategy for Countering International Terrorism, London: HMSO, 2006. 